Brit. J. vener. Dis. (1965), 41, 127.

\title{
GONOCOCCAL COMPLEMENT-FIXATION TEST IN COMPLICATED AND UNCOMPLICATED GONORRHOEA*
}

\author{
BY \\ BERTIL MAGNUSSON AND JAN KJELLANDER \\ Department of Dermato-Venereology and Department of Clinical Bacteriology, University of Gothenburg, Sweden
}

The complement-fixation reaction with gonococcal antigen (gonococcal complement-fixation test: GCFT) is based on the same serological principle, and has been known for about as long, as the Wassermann reaction. Up to the 1940's the GCFT was widely employed, but as improvements in cultivation techniques for gonococci were developed, interest in the complement-fixation reaction diminished. At present the reaction is no longer performed at the state public health laboratories in the USA. During the nineteen-thirties a vast number of investigations on the GCFT were recorded, among which the comprehensive monograph of Kristjansen (1930) from Denmark should be mentioned. However, very few reports on the GCFT reaction have been presented recently, and no Swedish survey has been made. A contributory factor to the indifference in which the GCFT is held may be its presumed limited specificity. Opinions are here divided and many point out that when used correctly, at least for differential diagnosis of gonorrhoeal complications, the reaction is still of value.

We have re-examined the GCFT because of the distressing increase in the number of persons with gonorrhoea during recent years (Gisslén, Hellgren, and Starck, 1961; Willcox, 1963), and the need of a differential diagnostic tool. We have primarily sought to answer the following questions:

(1) To what extent is the GCFT positive with (a) uncomplicated gonorrhoea? (b) complicated gonorrhoea?

(2) How specific is the GCFT?

\footnotetext{
* Received for publication June 5, 1964.
}

\section{Material}

The clinical material consisted of 300 patients, 150 men and 150 women, who were treated for gonorrhoea at Sahlgrenska Hospital, Gothenburg during 1961 and 1962; the diagnosis of gonorrhoea being verified by cultivation.

With the exception of 32 patients treated at the Department of Gynaecology for gonorrhoeal salpingitis, all the patients had been admitted to the out-patient or in-patient clinics of the hospital's Department of Dermatovenereology. Various symptoms of complications associated with gonorrhoea were present in a third of the total patients.

The control material consisted of 50 healthy blood donors and 108 patients with chronic bronchitis or extensive dermatosis. In order to lessen the possibility of gonorrhoeal infection patients over 40 years old were chosen for the dermatological control material. They had been accepted for treatment of extensive dermatoses of varying aetiology. All had a raised sedimentation rate, on average $50 \mathrm{~mm}$.; 3 of the patients had typical psoriatic arthritis.

Since positive GCFT reactions (Bang and Krag, 1942; Reyn, 1962a) are sometimes found with infections caused by Neisseria catarrhalis and $N$. flava, this control material of patients with chronic bronchitis consisted of those admitted to a department for pulmonary diseases (Renströmska Hospital) and those treated for bronchial asthma (Department of Allergology, Sahlgrenska Hospital).

\section{Methods}

Specimens Examined.-At the patient's first visit, specimens for direct microscopy and cultivation for gonococci were customarily taken, in addition to a blood serum sample. A second serum sample was taken after treatment at the final control examination, that is to say, approximately four weeks later. If the patient returned, as requested, after an additional two months, another serum sample wạs taken, 
TABLE I

GCFT RESULTS IN 300 PATIENTS WITH GONORRHOEA WITH OR WITHOUT GONORRHOEAL COMPLICATIONS

\begin{tabular}{|c|c|c|c|c|c|c|c|c|c|c|c|c|c|c|c|}
\hline \multirow{2}{*}{\multicolumn{4}{|c|}{$\begin{array}{l}\text { Patients with } \\
\text { Gonorrhoea }\end{array}$}} & \multicolumn{4}{|c|}{ Patients without Complications } & \multicolumn{4}{|c|}{ Patients with Complications } & \multicolumn{4}{|c|}{ Total Material } \\
\hline & & & & \multirow{2}{*}{$\begin{array}{l}\text { No. } \\
100\end{array}$} & \multirow{2}{*}{$\begin{array}{c}\begin{array}{c}\text { Nega- } \\
\text { tive }\end{array} \\
66 \\
(66 \%)\end{array}$} & \multirow{2}{*}{$\begin{array}{c}\begin{array}{c}\text { Incon- } \\
\text { clusive }\end{array} \\
13 \\
(13 \%)\end{array}$} & \multirow{2}{*}{$\frac{\begin{array}{c}\text { Posi- } \\
\text { tive }\end{array}}{2 \begin{array}{c}21 \\
(21 \%)\end{array}}$} & \multirow{2}{*}{$\begin{array}{c}\text { No. } \\
50\end{array}$} & \multirow{2}{*}{$\begin{array}{c}\begin{array}{c}\text { Nega- } \\
\text { tive }\end{array} \\
14 \\
(28 \%)\end{array}$} & \multirow{2}{*}{$\frac{\begin{array}{c}\text { Incon- } \\
\text { clusive }\end{array}}{(2 \%)}$} & \multirow{2}{*}{$\begin{array}{c}\begin{array}{c}\text { Posi- } \\
\text { tive }\end{array} \\
\begin{array}{c}35 \\
(70 \%)\end{array}\end{array}$} & \multirow{2}{*}{$\begin{array}{c}\text { No. } \\
150\end{array}$} & \multirow{2}{*}{$\begin{array}{c}\begin{array}{c}\text { Nega- } \\
\text { tive }\end{array} \\
80 \\
(53 \%)\end{array}$} & \multirow{2}{*}{$\begin{array}{c}\begin{array}{c}\text { Incon- } \\
\text { clusive }\end{array} \\
\begin{array}{c}14 \\
(9 \%)\end{array}\end{array}$} & \multirow{2}{*}{$\begin{array}{c}\begin{array}{c}\text { Posi- } \\
\text { tive }\end{array} \\
\begin{array}{c}56 \\
(37 \%)\end{array}\end{array}$} \\
\hline Male & $\cdots$ & . & $\cdots$ & & & & & & & & & & & & \\
\hline Female & . & . & . & 100 & $\begin{array}{c}42 \\
(42 \%)\end{array}$ & $\begin{array}{c}8 \\
(8 \%)\end{array}$ & $\begin{array}{c}50 \\
(50 \%)\end{array}$ & 50 & $\begin{array}{c}13 \\
(26 \%)\end{array}$ & $\begin{array}{c}7 \\
(14 \%)\end{array}$ & $\begin{array}{c}30 \\
(60 \%)\end{array}$ & 150 & $\begin{array}{c}55 \\
(37 \%)\end{array}$ & 15 & $\begin{array}{c}80 \\
(53 \%)\end{array}$ \\
\hline Tota & & . & . & 200 & $\begin{array}{l}108 \\
(54 \%)\end{array}$ & $\begin{array}{c}21 \\
(11 \%)\end{array}$ & $\begin{array}{c}71 \\
(35 \%)\end{array}$ & 100 & $\begin{array}{c}27 \\
(27 \%)\end{array}$ & $\begin{array}{c}8 \\
(8 \%)\end{array}$ & $\begin{array}{c}65 \\
(65 \%)\end{array}$ & 300 & $\begin{array}{l}135 \\
(45 \%)\end{array}$ & $\begin{array}{c}29 \\
(10 \%)\end{array}$ & $\begin{array}{c}136 \\
(45 \%)\end{array}$ \\
\hline
\end{tabular}

Serological Tests.-The antigen used was a suspension of 20 strains of gonococci killed by heating at $60^{\circ} \mathrm{C}$. for 30 minutes. These strains were isolated at the Bacteriological Laboratory, Sahlgrenska Hospital, from patients in the Gothenburg area with acute gonorrhoea. The anti-complementary effect of the antigen was measured and the antigen dose adjusted accordingly. Fresh guineapig serum at the minimal haemolyzing dose (MHD) was employed as complement. The serum from the patient, inactivated at $56^{\circ} \mathrm{C}$. for 30 minutes was used diluted twofold from $1 / 5$ to $1 / 160$. An aliquot of $0.1 \mathrm{ml}$. of each of these three reactants was taken and, after a fixation time of 45 minutes at $37^{\circ} \mathrm{C} .0 .2 \mathrm{ml}$. of 2 per cent. sheep blood cell suspension and 4 MHD of rabbit amboceptor were added. The mixture was incubated for 30 minutes at $37^{\circ} \mathrm{C}$. when the final readings were made.

The results are presented in per cent. haemolysis for each serum dose. The reaction was judged to be positive if 50 per cent. or less haemolysis was noted in the lowest serum dilution (final dilution $1 / 15$ ). When $60-80$ per cent. haemolysis occurred at this dilution the result was judged to be inconclusive.

\section{Results}

Patients with Gonorrhoea.-From Table I it may be seen that about one-third of the patients without clinical complications of the disease had positive GCFT and about two-thirds of the group with gonorrhoeal complications were serologically posi-
TABLE II

GCFT RESULTS IN 100 PATIENTS WITH GONORRHOEAL COMPLICATIONS GROUPED ACCORDING TO DIAGNOSED COMPLICATION

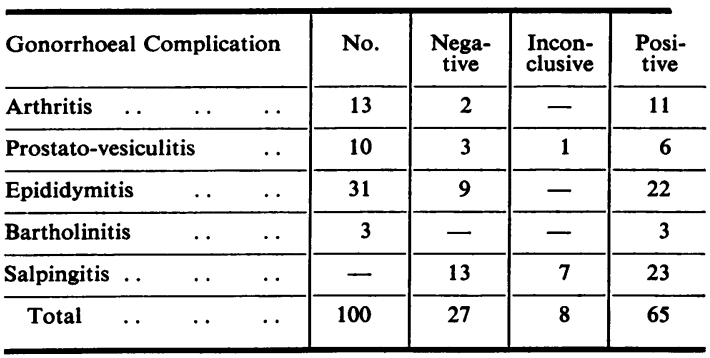

tive. A pronounced sex difference was apparent in the group without complications in which more than twice as many women as men showed positive GCFT. The distribution of the results in relation to the different types of gonorrhoeal complications is shown in Table II.

Control Material.-Table III shows that none of the healthy blood donors and patients with different dermatoses had positive GCFT, but 5 of the latter group showed inconclusive results. In the groups with chronic bronchitis 2 patients had positive and 2 inconclusive reactions.

TABLE III

GCFT RESULTS FOR 158 CONTROLS*

\begin{tabular}{|c|c|c|c|c|c|c|c|c|c|c|c|}
\hline \multirow{2}{*}{\multicolumn{5}{|c|}{ Diagnosis }} & \multirow{3}{*}{$\begin{array}{c}\text { No. } \\
50\end{array}$} & \multirow{3}{*}{$\begin{array}{c}\text { Male } \\
25\end{array}$} & \multirow{3}{*}{$\frac{\text { Female }}{25}$} & \multirow{3}{*}{$\begin{array}{c}\begin{array}{c}\text { Age Range } \\
\text { in Years } \\
\text { (Average) }\end{array} \\
\begin{array}{c}18-51 \\
(31)\end{array}\end{array}$} & \multicolumn{3}{|c|}{ GCFT } \\
\hline & & & & & & & & & \multirow{2}{*}{$\frac{\text { Negative }}{50}$} & \multirow{2}{*}{$\frac{\text { Inconclusive }}{-}$} & \multirow{2}{*}{$\frac{\text { Positive }}{-}$} \\
\hline Normal .Healthy b & ood donörs) & . & $\cdots$ & $\cdots$ & & & & & & & \\
\hline Dermatosis & . & . & $\cdots$ & $\cdots$ & 52 & 25 & 27 & $\begin{array}{c}41-86 \\
(65)\end{array}$ & 47 & 5 & 一 \\
\hline $\begin{array}{c}\text { Chronic bron } \\
\text { (Bronchial }\end{array}$ & $\begin{array}{l}\text { chitis } \\
\text { asthma) }\end{array}$ & . & $\cdots$ & $\cdots$ & 35 & 29 & 6 & $\begin{array}{c}31-72 \\
(57)\end{array}$ & 35 & - & 一 \\
\hline $\begin{array}{l}\text { Chronic bron } \\
\text { (Purulent b }\end{array}$ & $\begin{array}{l}\text { chitis } \\
\text { ronchitis, bro }\end{array}$ & chie & (sis) & $\cdots$ & 21 & 13 & 8 & $\begin{array}{c}18-74 \\
(47)\end{array}$ & 17 & 2 & 2 \\
\hline Total .. & . & . & $\ldots$ & $\cdots$ & 158 & $\begin{array}{c}92 \\
(58 \cdot 2 \%)\end{array}$ & $\begin{array}{c}66 \\
(41 \cdot 8 \%)\end{array}$ & $\begin{array}{c}18-86 \\
(50)\end{array}$ & $\begin{array}{c}149 \\
(94 \cdot 3 \%)\end{array}$ & $\begin{array}{c}7 \\
(4.4 \%)\end{array}$ & $(1 \cdot 3 \%)$ \\
\hline
\end{tabular}

* Fifty healthy blood donors and 108 patients with dermatoses or chronic bronchitis. 
The GCFT in Proportion to the Number of Courses of Penicillin.-Originally we had intended, among other things, to obtain data concerning the time interval between infection and the occurrence of a positive GCFT and to note how long reactivity persisted after the termination of treatment. For various reasons it proved difficult to obtain the essential information; for example, anamnestic data on when the infection occurred was in many instances indefinite. Infection opportunities had been many.

More than half of the material comprised patients who relapsed immediately after treatment and thus required more than one course of penicillin. The routine treatment consisted of one intramuscular injection of $1 \cdot 2$ m.u. procaine penicillin daily for two consecutive days. In relapses or in patients with complications the same daily dosage was given for five consecutive days. In Table IV this portion of the material is compared with the remainder of the patients who received only one course of penicillin. specific reactions even if we thereby lost some degree of sensitivity.

It is hazardous to compare investigations which have not been carried out with identical serological techniques. The comparisons drawn in the following discussion between our results and those of other investigations must be considered with this reservation in mind.

\section{Frequency of Serological Positivity in Patients with Gonorrhoea}

In the literature the frequency of positive GCFT in men with uncomplicated gonorrhoea varies from 10 per cent. (Nørgaard, 1956) to 50 per cent. (Kristjansen, 1930). Schmidt (1961) found seropositivity in 17 per cent. of the male patients with acute uncomplicated gonorrhoea. Our figure of 21 per cent. for the comparable patient group compares quite well with that of Schmidt.

In female patients with uncomplicated gonorrhoea Nørgaard (1956) found positive GCFT in 26 per cent.

TABLE IV

GCFT RESULTS IN RELATION TO NUMBER OF COURSES OF PENICILLIN

\begin{tabular}{|c|c|c|c|c|c|c|c|c|c|}
\hline \multirow{2}{*}{ Sex } & \multirow{2}{*}{ No. } & \multicolumn{4}{|c|}{ One Penicillin Course } & \multicolumn{4}{|c|}{ Two or more Penicillin Courses } \\
\hline & & No. & Negative & Inconclusive & Positive & No. & Negative & Inconclusive & Positive \\
\hline Male & 150 & 73 & $\begin{array}{c}52 \\
(71 \cdot 2 \%)\end{array}$ & $\begin{array}{c}7 \\
(9.6 \%)\end{array}$ & $\begin{array}{c}14 \\
(19 \cdot 2 \%)\end{array}$ & 77 & $\begin{array}{c}28 \\
(36 \cdot 4 \%)\end{array}$ & $\left(9 \cdot{ }^{7} \%\right)$ & $\begin{array}{c}42 \\
(54 \cdot 5 \%)\end{array}$ \\
\hline Female & 150 & 56 & $\begin{array}{c}19 \\
(33 \cdot 9 \%)\end{array}$ & $(3.6 \%)$ & $\begin{array}{c}35 \\
(62 \cdot 5 \%)\end{array}$ & 94 & $\begin{array}{c}36 \\
(38 \cdot 3 \%)\end{array}$ & $\begin{array}{c}13 \\
(13 \cdot 8 \%)\end{array}$ & $\begin{array}{c}45 \\
(47 \cdot 9 \%)\end{array}$ \\
\hline Total & 300 & 129 & $\begin{array}{c}71 \\
(55 \cdot 0 \%)\end{array}$ & $(7.0 \%)$ & $\begin{array}{c}49 \\
(38.0 \%)\end{array}$ & 171 & $\begin{array}{c}64 \\
(37 \cdot 4 \%)\end{array}$ & $\begin{array}{c}20 \\
(11 \cdot 7 \%)\end{array}$ & $\begin{array}{c}87 \\
(50.9 \%)\end{array}$ \\
\hline
\end{tabular}

The first group showed more positive GCFT than the patients who were treated with only one course. It should also be mentioned that the latter had been infected for a shorter period of time. The difference between these groups is statistically significant for the men, where the relapse group showed positive GCFT nearly three times as often as the group with a single instance of infection. In women the opposite tendency was noted, but the difference is not statistically significant.

\section{Serological Technique}

\section{Discussion}

First it must be stated that the serological technique is of decisive importance for the frequency of positive reactions. By working with different amounts of antigen, complement, and serum, and by varying the composition of the antigen one can influence the sensitivity of the reaction. Unfortunately, an increased sensitivity is usually accompanied by a diminished specificity. We sought to establish our reaction as having a minimum of non- in relation to initial infection and in 41 per cent. with repeated infection. Schmidt (1961) reported positivity in 37 per cent. of his female patients and in ours an even higher frequency of 50 per cent. was noted. Brown (1964) recently reported a complement-fixation test using a salt-extracted antigen and found 35 per cent. reactivity among 164 men with acute gonorrhoeal urethritis. Among 51 women in a penal institution in whom positive cultivation results had been obtained, $72 \cdot 5$ per cent. were reactive.

In our cases as well as in those described by Schmidt (1961), the GCFT in patients with acute uncomplicated gonorrhoea was positive more than twice as often for women as for men. The reason for this difference may be that a larger area of mucous membrane is generally involved in women than in men, therefore, a stronger antigenic stimulation may occur in the former group. Another possibility, which has been pointed out by, among others, Genner, Antons, and Boas (1932a), is that among the socalled uncomplicated female gonorrhoeal cases 
diverse but extensive simultaneous subclinical infections may be found. The fact that no preponderance of positivity was noted in women with definable clinical manifestations of gonorrhoeal complications supports this assumption. Indeed, in our material there was a slight tendency to the contrary, i.e., positive GCFT in 35 of 50 men and 30 of 50 women. This difference, however, is not statistically significant.

Our frequency figure of about 65 per cent. positive GCFT in the combined material of patients with complications is somewhat lower than that of Kristjansen (1930), which was between 68.5 per cent. and 100 per cent., and Thjøtta and Waaler's (1933) results of positivity in "nearly 100 per cent. of the patients with chronic or complicated gonorrhoeal infection". It is possible that the difference between our figure and that of Thjøtta and Waaler can be at least partly explained by the fact that we employed a somewhat higher serum dilution in the first tube $(1 / 15)$ than they did (1/12) and that their serological system was on the whole more sensitive than ours, due to a larger antigen dose.

Another factor which also may explain differences between frequency figures of different studies is the type of treatment given. Before the antibiotic era the treatment periods were much longer than nowadays, therefore the possibility of getting positive serology was greater.

\section{Specificity of the GCFT}

One of the objections directed against the GCFT as a diagnostic tool is that it is a comparatively unspecific reaction. The results of earlier investigations, as well as our own control material, hardly lend support to such a concept, irrespective of the level of specificity or the type of patient material investigated.

In material from venereal or urological clinics the reaction showed a high grade of specificity (Reyn, 1962). According to Kristjansen (1930) the GCFT is negative in all instances where gonorrhoeal infection can be excluded. In his material 1.4 per cent. positivity occurred in patients with no signs of such disease but where infection could not, however, be excluded. The reaction was positive in $\mathbf{9 \cdot 2}$ per cent. of the cases where no signs of the disease existed but where gonorrhoeal contact was believed to have occurred. The percentage error was therefore nil in favourable cases and 10.6 per cent. in unfavourable ones.

In sera originating from departments of internal medicine non-specific reactions appeared not infrequently. Thus Bang and Krag (1942) observed positive GCFT in such sera in $7 \cdot 2$ per cent. of the men and $6 \cdot 2$ per cent. of the women. The reaction was particularly often positive in patients with chronic bronchitis. It is possible that in such cases the positive GCFT is due to infection with $N$. catarrhalis or N. flava. These species and N. gonorrhoeae have antigens in common (Reyn, 1962a). Meningococcal infection can also give rise to positive GCFT, but this should hardly lead to any real differential diagnostic problem.

Our own control material showed a low frequency of positive reactions; two only were encountered in 158 persons investigated and the positive reactions were noted in two patients with chronic bronchitis. In one of these $N$. catarrhalis was isolated from a sample of tracheal secretion. The same species of bacteria was isolated from two other patients in the bronchitis group for whom inconclusive serological results were registered. On the other hand, many patients with an abundance of the genus Neisseriae in the tracheal secretion showed negative GCFT.

\section{Course of the GCFT}

The GCFT in epididymitis and acute gonorrhoeal arthritis should, according to Genner, Antons, and Boas (1932b) be positive within a week of the onset of these complications. Lomholt (1945) pointed out that in these conditions the reaction first becomes positive somewhat later, after some weeks.

In our total patient material the GCFT has generally become positive about ten days after the risk of infection, but due to the often uncertain information about the day of infection we have been unable to arrive at any reliable data concerning the time-interval between infection and the demonstration of serological positivity.

Concerning the duration of positivity calculated from the time of clinical cure, Kristjansen (1930) states that in general it should be about 1 to 2 months. Genner, Antons, and Boas (1932b) observed positive GCFT with epididymitis and arthritis persisting for 6 months to 2 years and the same authors (1932a) noted that with gonorrhoeal salpingitis 75 per cent. became serologically negative within a year while the remainder were still positive after 2 years. In our material we saw that the GCFT reverted to negative in about one month to one year or more after clinical cure. Here again our material is not suitable for more exact analysis.

\section{Conclusions}

In England, Harkness (1944) stated that "the gonococcal complement-fixation reaction on the blood serum does not afford any assistance in the diagnosis of this condition"; King and Nicol (1961) stated 
that "this test has only a limited value". It is possible that the latter evaluation of the usefulness of the GCFT may be the result of the curtailed employment of the technique during the last twenty to thirty years.

On the basis of the present results we feel that the reaction has unjustly fallen into far too deep obscurity. The GCFT can still retain a place as a diagnostic tool and may presently be useful, particularly since gonorrhoea, despite effective antibiotics, appears to be on the increase.

The indication for increased utilization of the GCFT reaction is as follows. A positive GCFT strongly indicates that the patient was infected with gonococci within the preceding one to three months, on condition that the presence of chronic bronchitis or meningococcal infection can be excluded. The reaction can therefore act as a valuable complement to direct smear and culture tests if these give inconclusive results.

Female patients with gonorrhoea without clinical signs of complications but with strongly positive GCFT should be observed longer and actually receive higher penicillin doses than are routinely employed because of the possibility of subclinical salpingitis. This increased dosage also holds for male patients with possible subclinical prostato-vesiculitis or epididymitis.

\section{Summary}

Of serum samples taken from 200 patients with gonorrhoea but without signs of corresponding complications 35 per cent. showed positive complement-fixation reactions with gonococcal antigen. The reaction was positive three times as often in women ( 59 per cent.) as in men ( 21 per cent.). Of the sera from 100 gonorrhoeal patients with different clinical signs of gonorrhoeal complications positive GCFT were demonstrated in 65 per cent. about evenly distributed according to sex.

Control sera from 158 persons without gonorrhoea showed positive GCFT in only two instances $(1 \cdot 3$ per cent.). These sera were from two patients with chronic bronchitis.

The results of the investigation speak favourably for the GCFT. Provided that meningococcal infection and chronic bronchitis can be excluded, the test has a high specificity and can be considered a worth-while complementary tool for the diagnosis of uncomplicated as well as complicated gonorrhoea.

\section{REFERENCES}

Bang, O., and Krag, P. (1942). Ugeskr. Lag., 104, 406. Brown, B. C. (1964). In Thayer, J. D., and Moore, M. B. (1964). Med. Clin. N. Amer., 48, 755.

Genner, V., Antons, K., and Boas, H. (1932a). Hospitalstidende, 75, 633.

Gisslén, H., Hellgren, L., and Starck, V. (1961). Bull. Wld Hlth Org., 24, 367.

Harkness, A. H. (1944). Brit. J. vener. Dis., 20, 2.

King, A. J., and Nicol, C. S. (1961). Ibid., 37, 92.

Kristjansen, A. (1930). "Komplementsbindingsreaktionen ved Gonorrhoe. En klinisk Studie". Nyt Nordisk Forlag, Copenhagen.

Lomholt, S. (1945). "Kønssygdommene og deres Behandling". Gads Forlag, Copenhagen.

Nørgaard, O. (1956). Acta derm.-venereol. (Stockh.), $36,150$.

Reyn, A. (1962a). Wld Hlth Org. VDT, 294, 16.

(1962b). Proc. north. derm. Soc., p. 60.

Schmidt, H. (1961). Ugeskr. Lag., 123, 749.

Thjøtta, T., and Waaler, E. (1933). Norsk Mag. Lagevidensk., 94, 286.

Willcox, R. R. (1963). Brit. J. vener. Dis., 39, 214.

Test de fixation du complément vis à vis du gonocoque dans des cas de gonorrhée avec ou sans complications

\section{RÉSUMÉ}

Parmi 200 échantillons de sérum provenant de sujets atteints de gonorrhée non compliquée, $35 \%$ montrèrent une réaction de fixation du complément positive en présence du gonocoque. Le nombre de réactions positives fut trois fois plus grand chez les femmes (59\%) que chez les hommes (21\%). Parmi 100 échantillons de sérum provenant de malades atteints de gonorrhée compliquée on trouva une réaction de fixation du complément positive (GCFT) dans $65 \%$ des cas, répartie de façon identique dans les deux sexes.

Des examens de contrôle faits sur le sérum de 158 personnes non atteintes de gonorrhée, ne furent positifs que dans 2 cas $(1,3 \%)$. Ces deux sujets souffraient de bronchite chronique.

Les résultats de ces investigations prouvent la valeur du test de fixation du complément (GCFT). Pourvu qu'une infection méningococcique ou une bronchite chronique soit exclue au préalable, ce test a une haute spécificité et on peut le considérer comme un élément complémentaire de valeur dans le diagnostic de la gonorrhée compliquée et non compliquée. 